\title{
PATRIOTISM AS A VALUE: ESSENCE AND FUTURE PROSPECTS
}

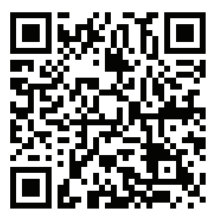

To cite this article:

\author{
Ivan Bekh, Dr. Sc., Prof. \\ Director, Institute of Problem on Education, \\ National Academy of Educational Sciences of Ukraine \\ Kyiv, Ukraine \\ ipv_info@ukr.net \\ https://orcid.org/0000-0002-4763-1673
}

Bekh, I. (2018). Patriotism as a value: essence

and future prospects. Education: Modern Discourses, 1, 185-191.

https://doi.org/10.32405/2617-3107-2018-1-18

\begin{abstract}
The article is devoted to the problem of patriotism based on the unity of its cognitive and emotional components. Therefore, patriotism as a social phenomenon has been characterized. Moreover, patriotism has the essential indicators, which are practically manifested through personality's behavior, action and communication. The author defines patriotism as an unconditional and highly meaningful feeling-value, which characterizes the person's attitude towards people, homeland, state and oneself. Unconditional aspect of patriotism means that the feeling of patriotism cannot be founded on external forms of encouragements. The highly semantic aspect of patriotism is not associated with the lower, existential needs, but with the highest life determinants of personality. According to a conceptual definition of patriotism, the author proposes the basic components that serve as diagnostic signals to determine its degree of development in a particular personality. A set of regulations, based on deep psychological mechanism, is practically significant for educators in order to organize the process of developing a feeling of patriotism. As a result, they are very effective in the educational process.
\end{abstract}

Key words: educational regulations; educational process; patriotism; personality; spiritual and moral antinomy; self-spiritual; components of patriotism.

\section{INTRODUCTION. PROBLEM STATEMENT}

The problem of patriotism affects the most sensitive sphere of personality. In the last few years, there has been a growing interest of the main part of Ukrainian society in patriotism, which is primarily the result of favorable coincidence of individual psychological, social, and family-related factors.

At the macro level, these favorable factors are not enough for a feeling of patriotism. D. Brooks argues that "we are surrounded by culture that teaches us to promote and advertise ourselves, to develop the skills we need to succeed, but it is not sufficiently stimulating spiritual development" (Brooks, 2015).

One of the most significant current discussions is to renew education by improving the educational process through formation of patriotism, careful attitude towards national, historical, and cultural values, traditions and achievements of Ukrainians. 


\section{LITERATURE REVIEW}

In recent years, there has been an increasing amount of literature on problem of patriotism. To solve this issue, researchers have proposed various methods of teaching students how to become a patriot. Previous studies indicate that patriotic education plays an important role in spiritual development of young personality. V. Sukhomlynskyi points out that patriotism has an active character and we need to teach children to seek their place in the life of the country, to fight against the disadvantages of society as well (Sukhomlynskyi, 1971).

For several years great effort has been devoted to the study of patriotism. Many studies have been focused on the essence of patriotism, its concrete historical character (Kateb, 2007; Königs, 2012; Moore, 2009; Primoratz, 2002; Soutphommasane, 2012). The methods of patriotic education of students of different age have been carried out (Archard, 1999; Zdenko, 2011). The possibility of teaching patriotism in academic and extra-curricular activities have been widely investigated (Nussbaum, 2012; Zembylas, 2014). In the literature, several theories have been proposed to define concept of patriotism (Arneson, 2005; Callan, 2006; Hulas \& Fel, 2015; Kateb, 2007; Kleinig, Keller \& Primoratz, 2015).

Although several studies have indicated that problem of patriotic education have a great significance in a general education, little attention has been paid to effective techniques of patriotic education in real life.

The purpose of the study is to define the notion of patriotism and specific techniques of its formation based on generalization of current researches on this urgent problem.

\section{METHODOLOGY}

The leading methodological idea in solving the problem of patriotism lies in the fact that there are no pure acts of cognition: each act of cognition has an element of attitude. Therefore, an integrity arisen from this idea allowed formulating an explanatory principle. It represents the psychological and methodological basis how to organize the process of education of the feeling of patriotism as well as transform it into the main value of students.

Using the key pattern of emotional experience as irradiation in terms of attraction to group emotional unanimity, we propose an innovative program aimed at acquiring patriotism as a value by humanity in general. The stability of this spiritual phenomenon is ensured by the interaction between mechanisms of consciousness and self-awareness, which allows person to reflexively realize it in practice at once.

\section{MAIN RESULTS}

The author's attention was focused on the feeling of patriotism as a direct emotional response of person to powerful external factors. We also have considered the patriotism as an indicator of spiritual growth of personality.

Patriotism is the strongest feeling of human unity. Its apogee qualifies as a state of complete harmony ("One heart and one soul"). However, this unity is not isolated, but it is connected with real life that realizes great goals of the people, the homeland, and the state. Kierkegaard defines this unity as the "sacred bonds that connect people" (Kierkegaard, 2013), the person's life is empty without patriotism. 
We started by defining "patriotism" as is a special, unconditional and highly meaningful feeling-value, which characterizes the person's attitude towards people, homeland, state and oneself. We will draw attention to the unconditional and highly meaningful aspects of patriotism in this definition. Unconditional aspect of patriotism means that the feeling of patriotism cannot be founded on external forms of encouragements. The highly semantic aspect of patriotism is not associated with the lower, existential needs, but with the highest life determinants of personality.

Based on our theoretical ideas, the feeling of patriotism consists of the basic components such as:

1) Love for people, the homeland, and the state;

2) Active devotion to the homeland;

3) Socially meaningful purpose;

4) Moral stability;

5) Readiness for self-sacrifice;

6) Having self-esteem.

The current study found that proposed components are necessary and sufficient in the context of feeling of patriotism as integrity. Indeed, in other research circumstances, these constituents can be expanded. It often happens, because, for example, purposefulness is objectively linked with patience, perseverance, perseverance. Therefore, they (along with other complementary components) are sometimes included in the structure of patriotism.

Moreover, self-esteem is an innovative component in the structure of patriotism. The results of this study confirm the assumption that patriotism has behavioral and activating role as the person's attitude towards oneself, as opposite to other components as external attitudes.

The most interesting finding was that all traditional definitions of patriotism it is mandatory to include love for people, homeland and state in its structure. Some psychologists suggest that instead the construct of "love" should be used the construct of "respect", arguing that the concept of "love" do not have a clear meaning.

Yet we will use the definition of love, trying to give it more logical rigor. In terms of education it is important to know that love-passion originally develop based on the mechanism of favour. In contract, students' love for the people, homeland and state happens in the process of overcoming their exclusion from public life in its highest values. This is often due to the students' lack of prudent and primitive motivation.

In order to find the effective ways of patriotic education, it is possible when the feeling of patriotism will be considered only within the limits of the great spiritual human values. The fact is that every highly meaningful spiritual value (for example, charity, care for others, patience) causes patriotism as value.

Patriotism as a complex feeling-value arises under the influence of spiritual, moral, civil, national education. It is impossible to love one's own people and homeland without loving one's family and relatives. Therefore, there should be a combination patriotic education and the above-mentioned types of education.

Patriotism is a profound human feeling. However, it becomes a higher value, when it is not isolated only in the inner world of personality, but when it has external realization into person's patriotic behavior that is a real indicator of its development.

Accordingly, the main educational goal of the teacher should be to ensure the transition from the student's desire of patriotism as a value to the patriotic act. It is 
interesting to note that there are situations in the educational process when student declares the statement, for example, "I want to be honest and genuine". This statement calms educator to believe that student has achieved the goal. Nevertheless, but there is no place for practical realization student's willing in the student's spiritual structure. Therefore, the student should be a subject of a patriotic act in order to achieve this inner value.

Patriotism is the action of the personality in the present, but must predict future. Superficially, there is nothing special in this perspective for the functioning of patriotism, as all other educational achievements are oriented at the person's future. However, in this case it is only the individual future of student. The personal questionnaire has the question "What person will you be in 10-15 years?" As for the feeling of patriotism, the future is connected not only with a separate personality, but also with the relatives, native land, people, homeland, state. "What will they be as a result of my actions?" This question should be answered by student. For that reason, patriotic personality must deliberately prepare oneself to the future and consider it as the meaning of one's own life.

Patriotism correlates with the moral responsibility of the personality, both with the current national situation and the responsibility for the past generations, the heroes who asserted the state, national self-consciousness and patriotism. As a consequence, patriotic education should be based on the heroic history of our people.

Furthermore, student's perception of the feeling of patriotism should occur on the basis of spiritual and moral antinomy (opposition). At the level of setting the educational goal, the antonymic pairs ought to be as the following: "You are patriotically imperfect You are patriotically perfect". In this way, the direction of the processes of consciousness and self-consciousness of the young personality are determined in educational process. At the level of ethical content, the value opposition can be such as: devotion to the case formal attitude to the case, love for the homeland - indifference for the homeland, etc.

The student must correctly determine the correspondence between opposite patriotic formations - the initial patriotic deeds and perfect patriotic - in the following directions:

- Valuable patriotic action both for others and oneself (one's action brought benefits to another person and earned respect for oneself).

- Meaningful growth of both actual motives and potential motives (not only individual motives, but social motives).

- Developmental dynamics of both present self-spiritual and future self-spiritual.

The success of the process of patriotic education depends on how to block egocentrism (arrogance, pride, desire for power, etc.) and how to be unselfish.

The problem of patriotism is multifaceted. Therefore, if we combine the efforts of state, society and education, it will possible to achieve considerable progress in solving this issue.

We offer a number of scientific statements that help teacher in patriotic education of students.

Statement 1. Patriotism can be as a supreme value of people, when patriotism is the leading value in the person's inner spiritual structure. Furthermore, it should be taken into account that the degree of individual significance of spiritual values may be different. For that reason, values that are part of the structure of patriotism (active devotion to the homeland, moral stability, readiness for self-sacrifice, self-esteem) will be more important for one person than another. 
This spiritual state cannot arise spontaneously. So, it must be developed special mind of young person that can be able to understand extremely complicated realities as integrity. These categories are the people, the homeland, and the state. This mind is defined as global mind. Students have to learn how to think globally. In the context of patriotic education, this means that students aware the essential characteristics of these categories. In addition, students can monitor changes that occur in their mind, predict progressive conditions as well.

An important point is that students make such decisions not in isolation, but effectively involved in life their people, homeland and state. All students' deeds (both small and large) are united by the main motive - to be faithful to their feeling of patriotism. If students can be always included in this activity, they will act like patriots.

Statement 2. Our psychological and pedagogical sciences claim that the formation of personality is associated with one's ability to avoid conflicts, especially social conflicts. For instance, conflicts between person and environment, person and community, person and the country). This inner motivation should be changed in radically different way: the person faces the conflict and understand one's own individuality. This direction is inherent for a person with a high level of patriotism.

Statement 3. These days, researches have shown that there is a person with a low level of patriotic education who often proclaims correct thoughts and even has desire for meaningful values, but they are not forced by one's own spirituality. Only the person's transition from the position "I know" to the position "I want" will indicate that the personality goes ahead to the higher level of spirituality.

Statement 4. Patriotism requires a person's deeply spiritual attitude towards social environment. Therefore, modern scientific researches must be methodologically coordinated with the problem of patriotic feelings of the community - both past and present generation. The first thing that should be developed in a growing personality is the ability to be a part of human integrity.

Statement 5. The main condition for providing sense of national unity within the nation, which patriotism requires, is to determine person's patriotic attitude towards another particular individual in connection with patriotic attitude towards the whole nation. At the same time, young personality awareness of concept "nation" through understanding a small close group, gradually expanding it. The patriotic subject-subject relations must be objectified in the sense of "We are partners" in terms of the same degree of patriotic feeling. These partners have emotional experience as real associates and friends.

Statement 6. The strong word has a great educational impact, so it is necessary to create texts of patriotic theme. Otherwise, these texts can be ineffective. The emotionally text is the result of its translation by an indifferent person who expresses a full power of one's own experience. However, on the other hand, if the text contains a few emotionally colored situations, then even a highly skilled educator cannot transform it into a living story that would cause the necessary emotional student's response.

We recommend a set of regulations for organizing the process of patriotic education.

Regulations 1. The effective process of patriotic education must include the following elements:

a) Deep understanding of a student;

b) Absolute acceptance of a student;

c) Recognition of a student as a supreme value;

d) Fair attitude towards a student. 
Regulations 2. The main condition of productive process of patriotic education is the objective orientation of student's life, which can definitely be emotional. It is represented by the experience of suffering, sorrow, frustration, etc.

Regulations 3. Patriotism as a value is a mental and emotional internal structure. The mental component gives it awareness. On the other hand, the emotional component gives it meaning and significance for students. Students have only knowledge of the value of patriotism, which does not cause it to a patriotic act. The complexity of the process of patriotic education is not related to knowledge about patriotism, but how to give it an appropriate meaning through person's emotional experience.

Regulation 4. The abstract form of patriotism is not assimilated into the existing spiritual and moral structure of students. Accordingly, educator should ensure the first meeting of students with a real patriotic act. That means that an abstract patriotism as a value should occurs in the form of concrete everyday actions connected the students to real-world experiences.

Regulations 5. Students should consider the opposite value - the lack of patriotic value - to the person's patriotic value. Firstly, this way of patriotic education maximally activates the process of student's spiritual self-consciousness. Secondly, when the content is presented in opposition, student solves the controversy and accepts a certain position.

Regulations 6. Educators should always block student's egocentrism (domination, arrogance, desire to power, etc.), because it determine the success of the process of patriotic education.

Regulations 7 . The stage of motivation to patriotic action is a very important in in educational process. Although students need patriotism as a value, yet they are not ready to realize it practically. Consequently, students can combine their all spiritual values and create an impulse for a patriotic act with the teacher's help. This can be objectified in the statement "I will act like a patriot".

Regulations 8. Both teacher and student should analyze the student's motives for a patriotic act, how this process works, as well as its outcome (benefit for people and one's own spiritual profit). In addition, tutor should show their satisfaction for the students' actions and encourage them to self-satisfaction.

Regulations 9. Patriotic education must occur under forms of communication and behavior adapted to students' needs that do not cause humiliation, do not infringe their rights, and do not manipulate them.

Regulation 10. The great basis for real patriotism is an influence of spiritual, moral, civil, state, and national education, on which the true patriotism of a person can grow. Overall, patriotism correlates with a person's moral responsibility: not only for the current national situation, but also for the past generations who asserted the statehood fostering national self-consciousness and patriotism.

\section{CONCLUSIONS}

From the research that has been carried out, it is possible to conclude that patriotic education is a comprehensive, systematic and purposeful activity of public authorities, non-governmental organizations, families, schools, and other social institutions in order to develop a higher level of patriotic consciousness, a loyal feeling, love of one's homeland, readiness to build democracy as well as fulfill one's civil duties to protect national interests, desire to maintain integrity and independence of Ukraine, to promote unity 
of Ukraine, civil peace and harmony in society. Therefore, a successful solution of this crucial issue will be able in genuine social unity.

The proposed techniques of patriotic education can be readily used in practice. Based on the findings presented in this paper, work on the remaining issues is continuing and will be presented in future papers.

\section{REFERENCES}

Archard, D. (1999). Should we teach patriotism? Studies in Philosophy and Education, 18, 157-73. Arneson, R. J. (2005). Do patriotic ties limit global justice duties? Journal of Ethics, 9, 127-50.

Brooks, D. (2015). The road to character. New York: Random House.

Callan, E. (2006). Love, idolatry, and patriotism. Social Theory and Practice, 32, 525-46.

Hulas, M., \& Fel, S. (Eds.). (2015). Intricacies of patriotism: Towards a complexity of patriotic allegiance, Frankfurt am Main: Peter Lang.

Kateb, G. (2007). Are patriotism and universalism compatible? Social Theory and Practice, 32, 609-24.

Kierkegaard, S. (2013). Fear and trembling. New Jersey: Princeton University Press.

Kleinig, J., Keller, S. \& Primoratz, I. (2015). The ethics of patriotism: A debate. Oxford: Wiley Blackwell.

Königs, P. (2012). Patriotism: A case study in the philosophy of emotions. Grazer Philosophische Studien, 85, 299-309.

Moore, M. (2009). Is patriotism an associative duty? Journal of Ethics, 13, 383-99.

Nussbaum, M. (2012). Teaching patriotism: Love and critical freedom. University of Chicago Law Review, 79, 215-51.

Primoratz, I. (2002). Patriotism: A deflationary view. Philosophical Forum, 33, 443-58.

Soutphommasane, T. (2012). The virtuous citizen: patriotism in a multicultural society. Cambridge: Cambridge University Press.

Sukhomlinskyi, V. (1971). Rozhdenie grazhdanina [The birth of the citizen]. Moskva: Molodaia gvardia. (in Russian)

Zdenko, K. (2011). Is education for patriotism morally required, permitted or unacceptable? Studies in Philosophy and Education, 30, 127-40.

Zembylas, M. (2014). The teaching of patriotism and human rights: An uneasy entanglement and the contribution of critical pedagogy. Educational Philosophy and Theory, 46 (10), 1-17. 